
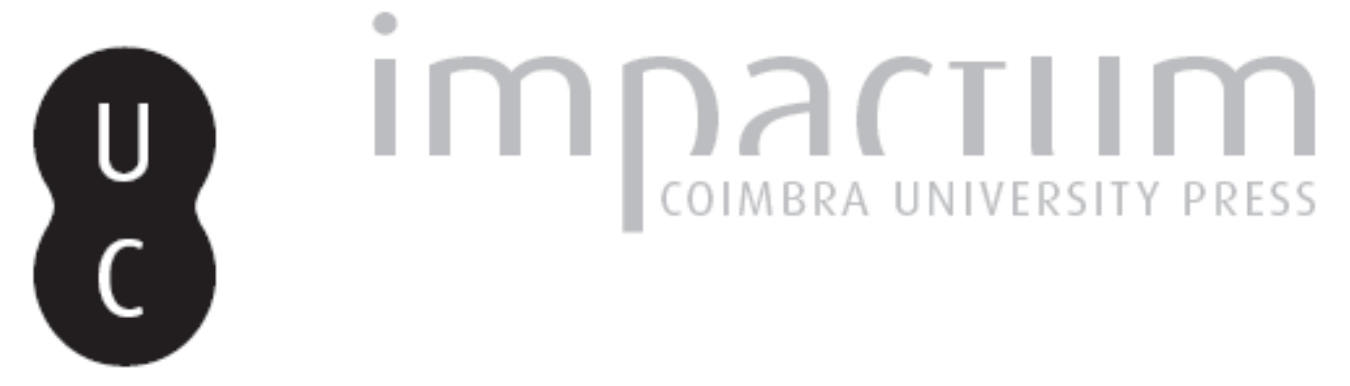

A Santa Casa da Misericórdia de Coimbra e o empréstimo de dinheiro a juros (17531765)

Autor(es): $\quad$ Elias, Luís Filipe da Cruz Quaresma

Publicado por: Centro de História da Sociedade e da Cultura

URL persistente:

URI:http://hdl.handle.net/10316.2/39521

DOI:

DOI:http://dx.doi.org/10.14195/1645-2259_10-1_11

Accessed : $\quad$ 26-Apr-2023 12:07:24

A navegação consulta e descarregamento dos títulos inseridos nas Bibliotecas Digitais UC Digitalis, UC Pombalina e UC Impactum, pressupõem a aceitação plena e sem reservas dos Termos e Condições de Uso destas Bibliotecas Digitais, disponíveis em https://digitalis.uc.pt/pt-pt/termos.

Conforme exposto nos referidos Termos e Condições de Uso, o descarregamento de títulos de acesso restrito requer uma licença válida de autorização devendo o utilizador aceder ao(s) documento(s) a partir de um endereço de IP da instituição detentora da supramencionada licença.

Ao utilizador é apenas permitido o descarregamento para uso pessoal, pelo que o emprego do(s) título(s) descarregado(s) para outro fim, designadamente comercial, carece de autorização do respetivo autor ou editor da obra.

Na medida em que todas as obras da UC Digitalis se encontram protegidas pelo Código do Direito de Autor e Direitos Conexos e demais legislação aplicável, toda a cópia, parcial ou total, deste documento, nos casos em que é legalmente admitida, deverá conter ou fazer-se acompanhar por este aviso.

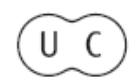




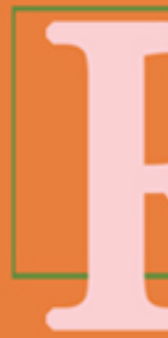

\section{evista de História}

da Sociedade e da

Cultura

\section{Tomo I}

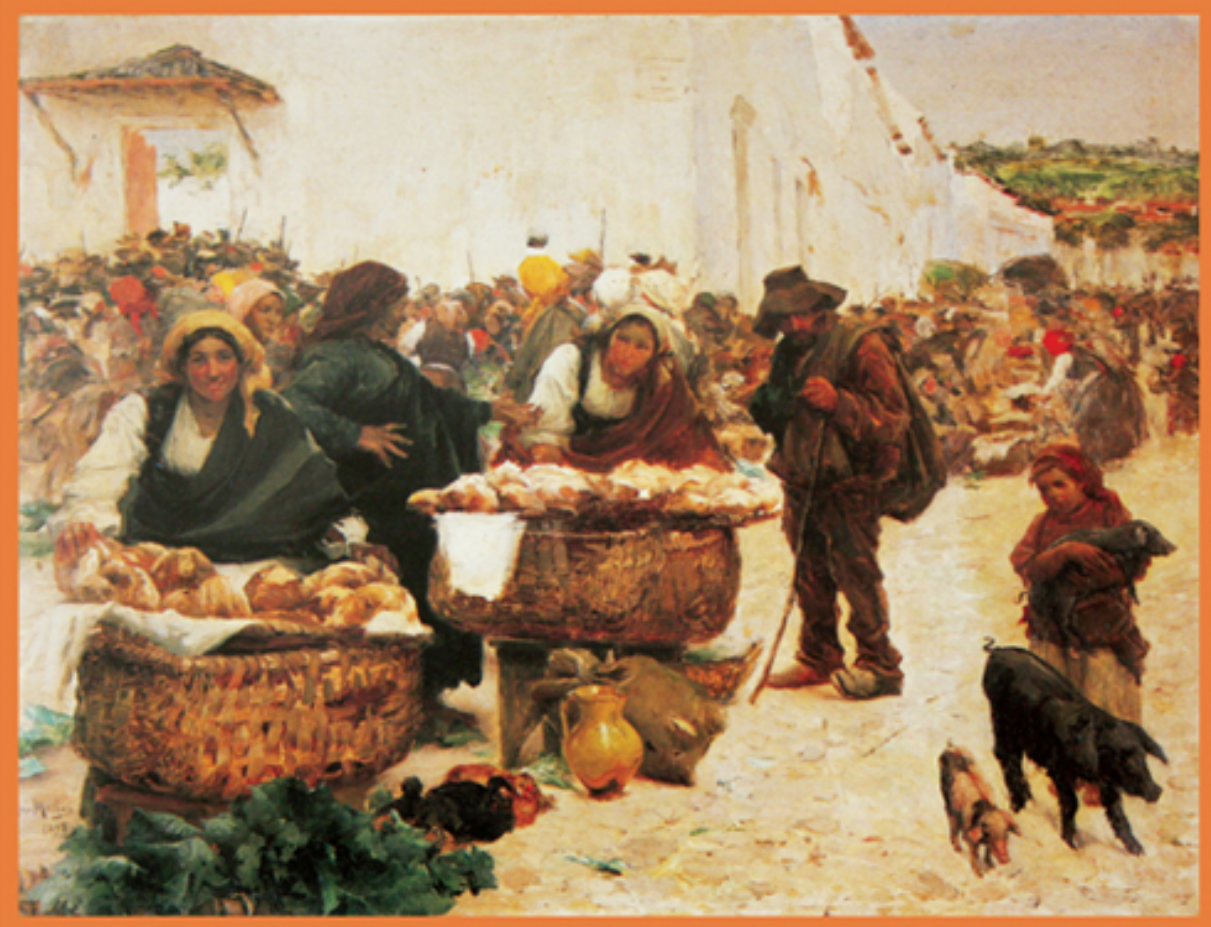

Centro de História da Sociedade e da Cultura Universidade de Coimbra

Coimbra 


\title{
A Santa Casa da Misericórdia de Coimbra e o empréstimo de dinheiro a juros (1753-1765)*
}

\author{
Luís Filipe da Cruz Quaresma Elias \\ Mestre em História Moderna pela Universidade de Coimbra \\ filipeluis@portugalmail.pt \\ Texto recebido em/ Text submitted on: 26/02/2010 \\ Texto aprovado em/ Text approved on: 26/04/2010
}

\section{Resumo/Abstract:}

Emprestar dinheiro a juros de 5\% era uma das principais fontes de rendimento das Misericórdias. Entre aqueles que mais beneficiavam dos capitais da Santa Casa de Coimbra estavam os próprios Irmãos, que usufruíam da cumplicidade das Mesas. Os motivos que levavam a solicitar os empréstimos eram variados. Como nem sempre os devedores cumpriam com as suas obrigações, a Misericórdia tinha ao seu alcance os mecanismos de execução das dívidas, os quais poderiam obrigar os devedores a realizar novas obrigações, conseguindo o prolongamento dos pagamentos. Noutros casos, pagando o total da dívida em atraso, os fiadores ficavam com as prerrogativas da Misericórdia, passando a credores. Ciente da importância do crédito para a sobrevivência da Irmandade, a Coroa criou um quadro legal que reforçava o poder executório das misericórdias, controlando e moralizando esta prática.

Money lending at 5\% interest was one of the sources of income of Misericórdias charity and welfare institution. Among those who benefitted most from the money of the Coimbra Misericórdia were the Brothers, who could also be members of the institution's administrations. There were several reasons for borrowing. Since not all borrowers fulfilled their commitments, Misericórdia had several mechanisms it could resort to to ensure debt repayment, which would obligate borrowers to contract new loans to reschedule old ones. In other cases, by paying the full amount of outstanding debt, the guarantors acquired the prerogatives of the Misericórdia, thereby becoming creditors. Aware of the role that credit played in the Brotherhood's survival, the Crown developed a legal framework, which enhanced the executive power of the Misericórdias, while controlling and moralizing this pratice.

Palavras chave/Keywords:

Juros; Crédito; Misericórdia; Dívida; Hipoteca.

Interest; Credit; Misericórdia; Debt; Mortgage.

* O presente trabalho resultou dos estudos feitos para a dissertação de mestrado A Misericórdia de Coimbra. Os irmãos, as suas práticas e a intervenção régia (1749-1784), apresentada em 2006 à Faculdade de Letras da Universidade de Coimbra, sob a orientação da Professora Doutora Maria Antónia Lopes. Retoma alguns trechos dessa obra e incorpora dados e reflexões novas, além da actualização da bibliografia. 
A inexistência de bancos no nosso país durante o Antigo Regime justificou a multiplicação das instituições que praticavam o empréstimo de dinheiro a juros. Esta forma de rentabilização do capital tinha destinos e clientelas diferentes, razão pela qual foi praticada por negociantes, desembargadores, instituições religiosas, confrarias e irmandades, com destaque para as misericórdias. A celebração de contratos desta natureza exigia o registo em documento próprio do montante emprestado e das hipotecas. Este mercado de dinheiro era fomentado pela Coroa no século XVIII que, entre outras medidas, fixou a taxa de juro a 5\% (alvará de 17 de Janeiro de 1757) para atrair os privados ${ }^{1}$. Neste estudo vamos fixar-nos no sistema creditício da Santa Casa da Misericórdia de Coimbra entre 1753 e 1765. Este período situa-se entre os acórdãos de 1748 e de 1766 que visam moralizar a prática de emprestar dinheiro a juros e tornar mais eficaz a cobrança de dívidas.

Com fundação inspirada no episódio bíblico da Visitação, as misericórdias viam inscritas nos seus compromissos quais as suas obrigações. Obrigações essas que vão sendo ampliadas por vontade régia, o que traduz uma confiança que os monarcas, na qualidade de seus protectores, depositam na instituição². Tornar as misericórdias instituições eficazes exigia uma boa gestão financeira traduzida num equilíbrio entre receitas e despesas. Foquemos a nossa atenção no lado da receita.

Isabel dos Guimarães Sá identifica como fontes de rendimento das misericórdias, entre outras coisas, a recolha de esmolas, a prática de empréstimo do dinheiro a juros e o arrendar/aforar os bens imóveis, muitos deles legados

1 Para uma perspectiva sobre a complexidade do crédito no Antigo Regime e as limitações no estudo do mesmo veja-se AMORIM, Inês - Gestão patrimonial e estruturas creditícias: rumos e directrizes em duas instituições: a Misericórdia de Aveiro e Convento de Freiras Carmelitas de Aveiro, no século XVIII (http://www2.egi.ua.pt/xxiiaphes/Artigos/a\%20 Inês Amorim.PDF, consultado em 2010/02/15).

${ }^{2}$ Sobre a acção das misericórdias no Antigo Regime veja-se LOPES, Maria Antónia Pobreza, Assistência e Controlo Social em Coimbra (1750-1850). Viseu: Palimage Editores, 2000; Araújo, Maria Marta Lobo de - Dar aos pobres e emprestar a Deus: as misericórdias de Vila Viçosa e Ponte de Lima (séculos XVI-XVIII). Barcelos: Santa Casa da Misericórdia de Vila Viçosa; Santa Casa da Misericórdia de Ponte de Lima, 2000; SÁ, Isabel dos Guimarães - Estatuto social e discriminação: formas de selecção de agentes e receptores de caridade nas misericórdias portuguesas ao longo do Antigo Regime. Saúde. As teias da discriminação social. Actas do Congresso Internacional Saúde e discriminação Social. Braga: Instituto de Ciências Sociais da Universidade do Minho, 2002, p. 303-334. 
em testamento ${ }^{3}$. Os testamentos eram, porventura, a melhor forma de trazer à instituição injecções de capital. Recomendava o compromisso da Santa Casa conimbricense, datado de 1620 , que a aceitação de testamentos devia ser cuidadosamente analisada por letrados ${ }^{4}$. Uma vez aceite a herança e analisada a vontade do testamentário, dever-se-ia proceder à inventariação de todos os bens móveis e de raiz que a compunham. Competia à Mesa converter estes bens em dinheiro para cumprimento das suas obrigações. Tal era feito através do arrendamento ou aforamento de propriedades rústicas ou da venda destes bens em pregão na praça. O dinheiro que entrava nos cofres da Santa Casa era rentabilizado num sistema de empréstimo a juros «ao serviço da caridade». Juros a cinco por cento que permitiam à irmandade acumular avultadas somas para pagar salários e cumprir com as suas obras caritativas ${ }^{5}$.

A importância da prática creditícia para o quotidiano da Misericórdia de Coimbra está bem atestada numa petição dirigida a D. João V. Pretendia-se autorização para que o cargo de procurador se tornasse perpétuo e com salário digno uma vez que «sendo a dita Santa Casa hua das mais opulentas do Reyno e consistindo mayor parte dos bens da sua administração em dinheiros a juros cujas cobranças dão de si inumeraveis pleitos $\rangle^{6}$. Foi também a questão dos créditos que esteve na origem do acórdão da Mesa de 27 de Março de 1748 e onde se tomaram medidas «para o bom regimen desta Santa Caza e para a boa administração de sua fazenda como também para corregir e desterrar alguns abuzos perniciozos que nella havia» ${ }^{7}$. Os primeiros quatro capítulos aprovados visavam tornar a prática do empréstimo de dinheiro a juro mais rigorosa e criteriosa: qualquer pessoa de fora da cidade teria que apresentar fiador da cidade; tratando-se de um suplicante estranho, a

3 SÁ, Isabel dos Guimarães - As misericórdias portuguesas de D. Manuel I a Pombal. Lisboa: Livros Horizonte, 2001, p. 47.

4 compromisso da Santa Casa da Misericórdia da cidade de Coimbra. Coimbra: Real Imprensa da Universidade, 1830, p. 41.

5 Cf. PARDAL, Rute - O sistema creditício na Misericórdia de Évora em finais do Antigo Regime (http://www2.egi.ua.pt/xxiiaphes/Artigos/a\%20Rute_Pardal.PDF, consultado em 2010/02/15).

6 Arquivo da Misericórdia de Coimbra (AMC), Livro de registo das Provisoens, Alvarás e Decretos concedidos a favor desta Santa Caza da Mizericordia de Coimbra ... (1708-1793), fl. $116 \mathrm{v}$.

7 AMC, Livro para os termos de rezolução e acórdãos da Meza desta Santa Caza da Mizericordia de Coimbra, Livro 4 (1695-1768), fl. 233-234. 
sua petição devia ser copiada e entregue a dois irmãos para, discretamente, recolherem informação do candidato e fiador; o cartorário da irmandade devia, durante o mês de Julho, elaborar uma pauta geral onde constassem os devedores, fiadores e obrigações de capitais em dívida; e foram reforçados os poderes do procurador para cobrar as dívidas em atraso.

\section{O empréstimo de dinheiro a juros}

O processo de pedir dinheiro emprestado à Misericórdia começava com a apresentação de uma petição à Mesa onde o interessado referia a quantia pretendida, os bens que hipotecava, o fiador e os bens por este hipotecados. Estas garantias asseguravam à instituição que, caso o suplicante não cumprisse com o pagamento da dívida, esta estaria coberta por bens, na maioria das vezes, de raiz. Era frequente o interessado fazer acompanhar o processo por um procurador, que não raras vezes era irmão da Santa Casa. Constatamos mesmo que os irmãos são presença constante nestes contratos, quer como suplicantes, procuradores ou fiadores. E são-no sobretudo os de primeira categoria, não raramente aparecendo antigos ou futuros provedores da instituição. Não será ousado concluir que a prática de empréstimo de dinheiro era um atractivo para os poderosos locais, que ao assumirem cargos

Gráfico 1 - Contratos de empréstimo registados nos livros de notas

(Maio de 1753 a Outubro de 1765)

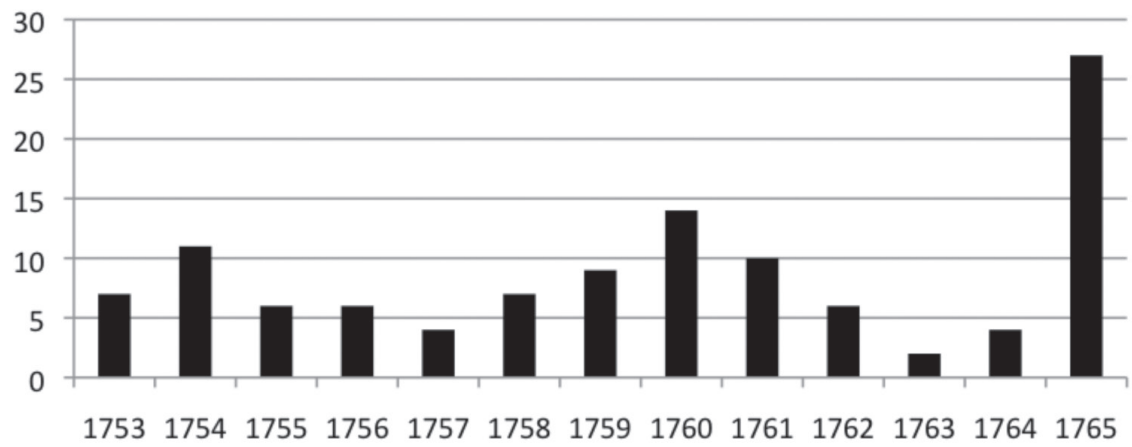

Fonte: Arquivo da Misericórdia de Coimbra, Livro de Notas No 18 a 21

8 Na elaboração dos gráficos foram excluídas as novas fianças solicitadas à Mesa como forma de garantir que o pagamento de um empréstimo seria feito, ainda que fora do prazo previsto. 
Gráfico 2 - Total de dinheiro emprestado, em contos de réis (Maio de 1753 a Outubro de 1765)

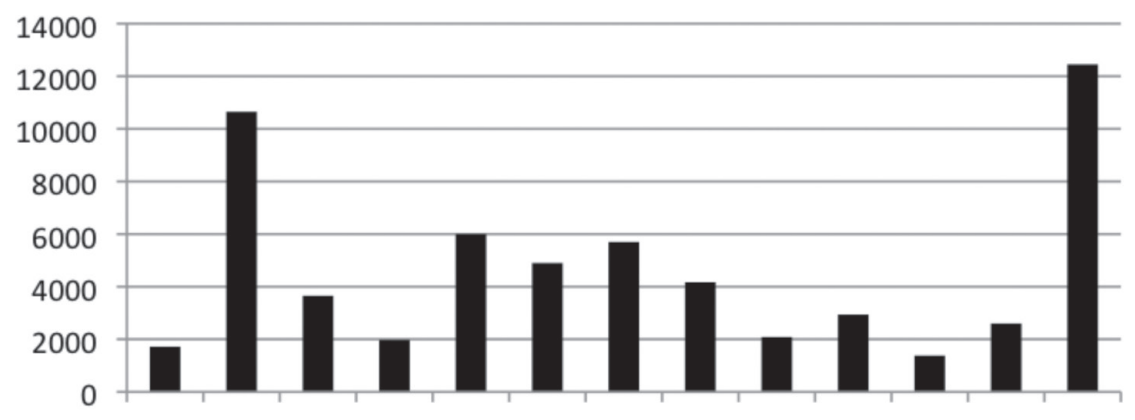

1753175417551756175717581759176017611762176317641765

Fonte: Arquivo da Misericórdia de Coimbra, Livro de Notas No 18 a 21

de destaque na Misericórdia podiam fazê-lo em benefício próprio ou das suas famílias e clientelas.

Uma observação geral dos gráficos permite-nos constatar que existe uma correlação entre o número de contratos creditícios celebrados pela Misericórdia e as somas envolvidas. Assim, quantos mais são os contratos, maiores as quantidades de dinheiro envolvidas. Os anos de 1754 e 1760, por exemplo, figuram entre aqueles que registam maior actividade. Detenhamo-nos no ano de 1757 por ser uma excepção à regra, uma vez que um número reduzido de contratos movimenta uma quantia de dinheiro considerável.

António Xavier Zuzarte Maldonado Cardoso 9 e Francisco de Morais de Brito da Serra ${ }^{10}$ contraíram um empréstimo conjunto de 6.000 cruzados,

9 Fidalgo da Casa Real, cavaleiro professo na Ordem de Cristo, familiar do Santo Ofício, capitão-mor da vila de Eiras, superintendente da coudelaria da comarca, correiomor de Coimbra, escrivão da receita e despesa do Hospital Real e sucessivamente vereador na Câmara de Coimbra entre as décadas de 40 e 70, era senhor do morgado dos Zuzartes. Foi também um nome constante nas lides da Santa Casa, onde foi eleitor, conselheiro, provedor (1753-54) e escrivão (1756/57). Para mais informação veja-se ELIAS, Luís Filipe da Cruz Quaresma - A Misericórdia de Coimbra. Os irmãos, as suas práticas e a intervenção régia (1749-1784). Tese de mestrado: FLUC, 2006, p. 33-34; RIBEIRO, Ana Isabel - A Comunidade de Eiras nos finais do século XVIII. Estruturas, redes e dinâmicas sociais. Coimbra: 2003, p. 19-20, 105-106 e 126-128; LOPES, Maria Antónia - Provedores e Escrivães da Misericórdia de Coimbra de 1700 a 1910. Elites e fontes de poder. Revista Portuguesa de História. Tomo XXXVI, vol. 2 (2002/2003) 203-274 (p. 211).

${ }^{10}$ Natural da Azambuja, fidalgo da Casa Real, cavaleiro professo na Ordem de Cristo, familiar do Santo Ofício e deputado dos Marachões. O seu nome é frequente nas lides 
3.000 cada um, no dia 7 de Agosto de 1757. O objectivo era a compra de acções no projecto estatal da Companhia Geral da Agricultura das Vinhas do Alto Douro. Os contratos, semelhantes entre si, dizem-nos que:

«por se achar habelitado na Junta do Contracto dos Vinhos para entrar em o mesmo com três açois que importavão em hum conto e duzentos mil reis cuja quantia tinha segurado com expiciais hypothecas e que duplicavão o valor alem da seguransa que a mesma Companhia faz que ficou obrigada in solidum aquelle credor a quem o suplicante tomar a juro o dito conto e duzentos mil reis e como o supplicante a quer haver desta Santa Caza pello dinheiro que se acha destinado para semilhante juro, pedindo enfim a conclusão de sua petição se lhe mandase lavrar escriptura da referida quantia debaixo das hypothecas e obrigaçois de sua sentença de habelitação» ${ }^{11}$.

O Estado fazia assim uso dos capitais desta e de outras instituições em proveito dos seus projectos para desenvolvimento e modernização do Reino. Estes dois empréstimos são também um retrato dos privilégios de que usufruíam os irmãos, beneficiados no acesso ao crédito por terem a seu cargo a administração da Santa Casa e pela solidariedade e cumplicidade dos seus pares ${ }^{12}$. Ora estes dois suplicantes obtêm o empréstimo um mês depois de deixarem os dois cargos mais importantes na gestão da irmandade, respectivamente escrivão e provedor. Francisco de Morais de Brito da Serra destaca-se como um dos nomes que mais recorreu ao crédito da irmandade. Além do caso supracitado, contraíra um empréstimo de 5.000 cruzados a 23 de Fevereiro de 1754 e outro de 600 mil réis a 7 de Agosto de 1765 .

camarárias (onde ocupou os cargos de vereador e escrivão) e da Misericórdia (foi eleitor, conselheiro, provedor na Mesa de 1755/56 e escrivão em 1762/63). Veja-se ELIAS, Luís Filipe da Cruz Quaresma - A Misericórdia de Coimbra ..., cit., p. 35-36.

${ }^{11}$ AMC, Livro de Notas, No 19 , fl. 77v-85.

${ }^{12}$ Cf. SÁ, Isabel dos Guimarães - A assistência: as misericórdias e os poderes locais in OLIVEIRA, César de (dir.) - História dos Municípios e do poder local: dos finais da Idade Média à União Europeia. Lisboa: Círculo de Leitores, 1996, p. 139; ABREU, Laurinda - As actividades creditícias das misericórdias de Setúbal e Lisboa (séculos XVII-XVIII) estudo introdutório (http://www2.egi.ua.pt/xxiiaphes/Artigos/a\%20LAbreu.PDF, consultado em 2010/02/16); MONTEIRO, Nuno Gonçalo - O Crepúsculo dos Grandes. A Casa e o Património da Aristocracia em Portugal (1750-1823). Lisboa: Imprensa Nacional Casa da Moeda, 2003, p. 391-396. 
A propósito deste último empréstimo a cumplicidade entre irmãos é total. $\mathrm{O}$ antigo provedor fez-se representar pelo seu procurador, o reverendo António Mendes, capelão da Santa Casa, e pretendia os 600 mil réis «para pagar humas cazas que arematou em praso na execução» feita pela Misericórdia «a Ignacio dos Santos mercador desta mesma cidade» ${ }^{13}$.

Ocupar um lugar na Mesa era ter acesso aos rendimentos da Misericórdia e desta forma intervir no mercado creditício, definindo quem beneficiava com os empréstimos. Daí não ser de estranhar que antigos ou futuros provedores e escrivães apareçam com frequência. Vejam-se os seguintes casos. Manuel José Coutinho ${ }^{14}$ consegue, a 25 de Junho de 1755, um empréstimo de 4 mil cruzados para pagamento de dívidas. Aires de Sá e Melo ${ }^{15}$, representado por João António de Sá Pereira, seu primo, fidalgo da Casa Real e tenente-coronel na praça de Almeida, recebe a quantia de um conto e duzentos mil réis a 16 de Setembro de 1759, numa altura em que já servia no governo central. Apesar de não mencionar o motivo de semelhante pedido, sabemos que hipoteca uma quinta na Várzea com todas as suas pertenças na zona extra-muros da cidade e umas fazendas livres que tem na Lousã (uma quinta, vinhas, terras de rega seca e olivais) ${ }^{16}$. José Correia de Melo e Brito de Alvim Pinto ${ }^{17}$ negoceia a quantia de um conto de réis a 5 de Maio de 1762. Apresenta como fiador o ferreiro Francisco José de Oliveira, um dos nomes que o acompanha como conselheiro de menor condição na Mesa a que

${ }^{13}$ AMC, Livro de Notas, No 21, fl. 150v-152.

${ }^{14}$ Fidalgo da Casa Real, cavaleiro professo na Ordem de Cristo, familiar do Santo Ofício e senhor dos morgados dos Coutinhos de Coimbra. Com uma passagem fugaz na vereação, foi um nome sonante da Misericórdia na qualidade de eleitor, conselheiro, escrivão (1740/42 e 1747/49) e provedor (1752/53). ELIAS, Luís Filipe da Cruz Quaresma - A Misericórdia de Coimbra..., cit., p. 35.

${ }^{15}$ Oriundo de uma família influente, era fidalgo da Casa Real e cavaleiro professo na Ordem de Cristo. Escrivão da Misericórdia em 1739/40, foi nome sonante da vereação coimbrã entre 1741 e 1749, embaixador, secretário de Estado e ministro de D. José e D. Maria I. Veja-se LOPES, Maria Antónia - Provedores e Escrivães da Misericórdia..., cit., p. 214-215.

${ }_{16}$ AMC, Livro de Notas, No 20, fl. 79-81v.

${ }^{17}$ Fidalgo da Casa Real, foi várias vezes vereador na Câmara. Teve uma ascensão fenomenal na Misericórdia: em 1757 presta juramento de admissão e é logo nomeado conselheiro, em 1758 serve como escrivão e em 1762/63 é o Provedor escolhido. Poucos anos depois sai de Coimbra para se fixar na vila de Sinde. Ver ELIAS, Luís Filipe da Cruz Quaresma A Misericórdia de Coimbra ..., cit., p. 36. 
presidirá nesse preciso ano de $1762^{18}$. Futuro escrivão e provedor, o cónego Rodrigo de Almeida Vasconcelos Barberino ${ }^{19}$, obteve a 13 de Junho de 1764 um crédito de 600 mil réis, tendo hipotecado, além dos bens de raiz, um casal e dois olivais, «o anno de morto do seu beneficio que tem na Santa Se desta cidade $»^{20}$.

A Misericórdia era também procurada pelos grupos não privilegiados. Afastados da vereação pelo Pacto de Fidalguia ${ }^{21}$, encontravam no compromisso da Santa Casa uma garantia de promoção social. Ser admitido na irmandade e ocupar um lugar no seu governo garantia reconhecimento social e, por consequência, afastamento face à base da pirâmide social. Os irmãos de menor condição, uma elite do Terceiro Estado, figuram entre aqueles que vêm na Misericórdia uma boa credora. Chegam mesmo a aparecer como fiadores dos irmãos de maior condição. Não será abusivo falar de uma rede clientelar e de interesses que se estabelece na Misericórdia. Já referimos o caso de Francisco José de Oliveira, ferrador. Fiador no contrato celebrado por José Correia de Melo e Brito de Alvim Pinto, vai ser um dos mesários mecânicos que o acompanha na Mesa por ele presidida meses depois.

Conseguir ser eleito/nomeado como mesário mecânico era partilhar o poder com os poderosos e por isso poder beneficiar dos rendimentos da instituição. Contraem no entanto somas mais modestas. Dois nomes sonantes na governança da Misericórdia, apesar de menor condição, o carpinteiro Alexandre Simões Ferreira e o armador Bento dos Reis contam-se entre aqueles que vêm nela uma boa credora. Bento dos Reis consegue contrair dois empréstimos num total de 150 mil réis (100 mil réis em 1760 e 50 mil réis em 1763). Em ambos os casos apresentou como fiador o mestre estribeiro, Manuel Luís e sua mulher, hipotecando a casa em que morava na Rua da Calçada ${ }^{22}$. Já Alexandre Simões Ferreira, portador de uma procuração

${ }^{18}$ AMC, Livro de Notas, No 21, fl. 40v-42.

${ }^{19}$ Cónego na Sé Catedral e fidalgo da Casa Real Admitido como irmão da Santa Casa em 1764, ocupou a escrivania entre 1767 e 1770 e foi provedor na Mesa de 1770/71. Ver ELIAS, Luís Filipe da Cruz Quaresma - A Misericórdia de Coimbra ..., cit., p. 37.

${ }^{20}$ AMC, Livro de Notas, $\mathrm{N}^{\circ} 21$, fl. 76v-78.

${ }^{21}$ Ver SOARES, Sérgio - O municipio de Coimbra da Restauração ao Pombalismo: poder e poderosos na Idade Moderna, 3 vols. Coimbra: Centro de História da Sociedade e da Cultura, 2001-2004.

${ }^{22}$ AMC, Livro de Notas, No 20, fl. 124v-126 e No 21, fl. 45-46. 
que lhe faz sua mulher, consegue um empréstimo de 600 mil réis em 1756 e 320 mil réis em 1765. Tendo como fiador o vigário de Alfarelos, Bento Cardoso Lucas, que se faz representar pelo procurador Manuel Baptista de S. José, cartorário da Santa Casa, hipoteca um casal que possui junto de S. Paulo de Frades (constituído por olivais e pinhais) e uma quinta perto de Lordemão (composto por vinhas, pomares e terras de rega) ${ }^{23}$.

Poder-se-iam evocar muitos outros casos para comprovar o quão aliciante era ter um cargo na governança da instituição e de que forma isto era um privilégio no acesso aos seus dinheiros. E mesmo quando um irmão morria, a família continuava a merecer a atenção da instituição e tratamento preferencial. É normal vermos as suas viúvas figurarem entre as devedoras.

Em 1758 D. Doroteia Maria de Sousa e Meneses, viúva de Manuel José Coutinho Pereira, consegue a quantia de cinco mil cruzados. Neste contrato Manuel Coutinho Pereira Forjaz, nome sonante da fidalguia coimbrã, aparece como procurador da mãe e do fiador Nicolau Pereira Coutinho de Sousa Meneses e Horta, fidalgo da Casa Real e senhor da redízima da Baía. Sem apresentar o motivo do pedido, hipoteca uma quinta que possui no bispado do Porto ${ }^{24}$. D. Maria Escolástica de Nápoles Teles de Meneses, viúva de Joaquim José Leitão, que tem como fiador José Correia de Melo e Brito de Alvim Pinto, já aqui referido, consegue um empréstimo de 200 mil réis em 1761. Este estatuto da viúva de irmão estende-se aos de menor condição. Veja-se a título de exemplo a viúva do ferrador João Gomes, Leonor Maria, que solicita a quantia de 200 mil réis «para com elles dar estado de religiozo a hum seo filho». Apresenta como procurador Manuel Baptista de S. José e como fiador o padre António Mendes, respectivamente cartorário e capelão da Santa Casa, hipotecando várias terras que tem em Fornos e seus arredores.

Mas o universo dos que contraem empréstimos com a Santa Casa não se esgota nos irmãos. Pelos juros competitivos, se não mesmo apetecíveis face a outras instituições que se dedicavam a esta prática, ela era procurada por outras personalidades menos distintas de Coimbra e até de fora dela.

\footnotetext{
${ }^{23}$ AMC, Livro de Notas, No 19 , fl. 47v-50 e No 21, fl. 132v-134v.

${ }^{24}$ AMC, Livro de Notas, $\mathrm{N}^{\circ} 20$, fl. 3-5v.
} 
O elemento feminino é uma realidade, embora a situação jurídica das mulheres as obrigasse ao acompanhamento masculino, fosse ele o marido ou o procurador. Quase todas as mulheres eram casadas e, na maioria dos casos, a petição fora precedida de uma procuração ao marido, a quem eram delegadas competências. Isabel Teresa da Visitação, moradora na Rua Larga e com estado conjugal não mencionado, só no ano de 1754 protagoniza dois empréstimos. Com procurações passadas ao padre Manuel de Oliveira Cordeiro em Março e a José Rodrigues de Gouveia em Julho, pediu um total de 600 mil réis. Mariana João, órfã de pai e única mulher declarada solteira, recebe em 1760 um total de 120 mil réis. Talvez por estar consciente de que o seu estado civil poderia levantar alguns obstáculos, apresenta um rol de três casais como fiadores: Francisco Simões Cigano e Rosa Maria, Francisco Simões e Joana da Conceição, Manuel Luís e Antónia Francisca. No ano de 1765 D. Antónia Maria Clara de Melo, da vila de Ançã, consegue um dos maiores empréstimos feitos no período analisado, sete mil cruzados, «para com elles remir algumas dividas que tem dispersas». É extenso o rol de bens imóveis que hipoteca, bem como a sua localização: Castelo de Viegas, Coimbra, Cernache, Pereira, Ançã, Vale da Feteira, Pena e S. Silvestre. Hipoteca ainda rendas e foros em géneros alimentares: 38 alqueires de milho e 2 de feijões que lhe paga João Varela; 5 alqueires de trigo e 6 de milho de Nicolau Francisco; 8 alqueires de milho de Joaquim Francisco Bichana; 8 alqueires de milho, 1 de feijão e uma galinha de António Simões; 20 alqueires de milho, 1 de feijão e uma galinha de Manuel Carvalho e 5 alqueires de trigo de Manuel dos Santos e Francisco de Figueiredo. O fiador é o filho, que cobre tudo com a hipoteca de uma quinta em S. Romão e os prazos que possui no Carregal ${ }^{25}$.

Também o elemento religioso recorre à Santa Casa para contrair empréstimos. No ano de 1754 duas irmãs, ambas religiosas em Celas, Josefa Antónia da Rocha e Marcelina Engrácia da Rocha, tomam a juro 500 mil réis para pagamento de dívidas familiares. Estas religiosas fazem-no a título individual, mas em 1760 o Seminário de Santa Maria, extra-muros da cidade, necessitado de dinheiro para obras recorre à Santa Casa. O procurador, padre Francisco da Costa Pereira, congregador do seminário, em nome do reitor

${ }^{25}$ AMC, Livro de Notas, No 21, fl. 155-157v. 
D. Nicolau Felisberto e de todos os irmãos congregados, pede a soma de 2.000 cruzados. Dada a natureza dos bens hipotecados, as rendas do arcediago de Penela, pertencentes ao seminário, faz-se a petição acompanhada de uma licença do bispo de Coimbra a autorizar este negócio ${ }^{26}$.

Os rendimentos da Misericórdia eram ainda procurados por pessoas de fora de Coimbra, o que talvez seja sinal das dificuldades por que passavam as suas congéneres noutras partes do país. Em 1757, Baltasar Jácome do Lago Rego, capitão dos granadeiros do Regimento de Aveiro, natural de Viana, e D. António de Lencastre de Carvalho Fonseca e Camões de Meneses, da cidade de Guimarães, conseguem da irmandade avultadas somas para comprar acções na companhia vinícola do Douro. O maior empréstimo concedido pela Misericórdia no período em análise foi de 12.500 cruzados ao desembargador Jacinto da Costa de Vasconcelos e Sousa, da vila de Soure, para «pagamento de varias dividas» ${ }^{27}$.

\section{Os motivos dos empréstimos}

O mercado de créditos português em contexto do Antigo Regime é relativamente pouco conhecido. No entanto, conclui-se que as razões que levam as clientelas a socorrer-se do crédito variam de instituição para instituição, o que não é de estranhar quando estas definem o perfil daqueles de quem se vão tornar credoras. E a Misericórdia de Coimbra não foge a esta regra. Esboçado o retrato dos suplicantes de crédito desta instituição, detenhamo-nos nas razões para o endividamento.

Muitos dos contratos celebrados não mencionam o motivo do empréstimo. No entanto, servindo-nos dalguns casos já atrás referidos, cremos que não será abusivo afirmar que a maioria dos solicitadores de crédito endivida-se à Misericórdia para poder pagar outras dívidas ${ }^{28}$. Além da concentração

${ }^{26}$ AMC, Livro de Notas, № 20, fl. 101-104. A propósito das obras no seminário veja-se ALMEIDA, Fortunato de - História da Igreja. Tomo III. Coimbra: Imprensa Académica, 1915, p. 309.

27 AMC, Livro de Notas, No 19, fl. 19-21v.

${ }^{28}$ Cf. COSTA, Américo Fernando da Silva - A Misericórdia de Guimarães: crédito e assistência social, Cadernos do Noroeste, vol. 11, nº 2, 1998, p. 156-159. 
das dívidas num só credor, beneficiavam dos juros baixos da irmandade. Vejam-se outros casos que sustentam e reforçam este ponto de vista.

Luís de Melo da Silva solicitou em 1755 a quantia de 450 mil réis para «pagar dividas aos religiozos descalços do Carmo e ao Doutor Policarpo Antonio de Carvalho» ${ }^{29}$. Em 1765 o reverendo Manuel de Araújo de Figueiredo, irmão da Santa Casa, pediu 500 mil réis «para pagamento que queria fazer a todos os seus credores a fim de ficar exempto delles e so obrigado a huma parte», hipotecando «todos os rendimentos que tem de hum beneficio que possui na Cathedral desta cidade como tão bem o anno de morto do mesmo beneficio» ${ }^{30}$. Semelhante foi o motivo da petição de Bento José do Rego que, para pagar as dívidas à «Irmandade dos Santos Martyres cem mil reis e cento e noventa mil reis a Bento Rodrigues Macedo morador nesta cidade e como por ora não tinha as ditas quantias para the satisfazer», socorreu-se da Misericórdia, que lhe emprestou 290 mil réis ${ }^{31}$. Saldar dívidas familiares foi o argumento de Miguel Pedro Tavares de Carvalho para contrair um empréstimo de 1 conto e 100 mil réis.

Os motivos dos empréstimos não se esgotam no pagamento de dívidas de natureza variada. Muitos são os que aproveitam a competitividade dos juros da instituição para oportunidades de negócio, sejam elas a aquisição de bens patrimoniais (terras ou edifícios) ou realização de obras. Muitas das propriedades provinham de execuções por incumprimento das obrigações aos credores.

Em 1754 José Simões Zambujo pediu 100 mil réis para poder comprar terras. No ano seguinte José Gomes e sua mulher contraíram a dívida de 125 mil réis para aquisição de uma casa na Rua do Quebra-Costas. Em 1758 o irmão da Misericórdia, Pedro Paulo, obteve 130 mil réis «para ratificação de umas cazas que possue livres e dezembargadas $»^{32}$. Luísa Francisca solicitou 200 mil réis «para concluir as obras de huma caza que andava fazendo» ${ }^{33}$. Ainda nesse ano de 1758 foi concedida a avultada soma de 4.000 cruzados ao capitão-mor da vila de Celorico, Diogo Henrique Coelho

\footnotetext{
${ }^{29}$ AMC, Livro de Notas, No 19 , fl. 42-44.

${ }^{30}$ AMC, Livro de Notas, No 21, fl. 89-91v.

${ }^{31}$ AMC, Livro de Notas, $\mathrm{N}^{\circ} 21$, fl. 135-137.

${ }^{32}$ AMC, Livro de Notas, No 20, fl. 19v-21v.

${ }^{33}$ AMC, Livro de Notas, No 20, fl. 21v-23.
} 
de Almeida, «para comprar humas fazendas $»^{34}$. Na petição que, em 1760, fez Francisco de Pina e Melo para obter a quantia de 2.000 cruzados é apresentado como motivo «pagar hum prazo que arematou hua execução que fizerão os religiozos de Sam Joam a Silverio Correia da Fonsequa». Este contrato tem a curiosidade de ter na sua parte burocrática gente das lides universitárias, dois opositores às cadeiras de Cânones, doutor João Mendes da Costa e doutor Vicente Rodrigues Ganhado, respectivamente procuradores do suplicante e do seu fiador ${ }^{35}$. O bacharel Bento Nogueira, irmão da Santa Casa e nome importante entre os que serviram de mesários, socorreu-se da instituição para um empréstimo de 400 mil réis para comprar umas casas em Montarroio ${ }^{36}$. A 25 de Agosto de 1765 é o doutor Luís da Cunha quem contrai um empréstimo de 320 mil réis «para negocio de sua utilidade e tão bem para pagar da mesma quantia sessenta mil réis a Donna Jacinta Josefa de Souza e cento e sincoenta e sete mil reis a Manoel Felis da Sylva mercador». Mais uma vez o cartorário da Misericórdia, Manuel Baptista de S. José, aparece como procurador ${ }^{37}$.

Como credora, a própria Santa Casa tinha poderes executórios. Sempre que um devedor não cumpria com as suas obrigações a Misericórdia usava esta prerrogativa. Foi o que aconteceu quando a irmandade fez execução das dívidas a Domingos da Rocha, que entretanto falecera. Ora, Manuel Simões dos Reis, que arrematara ao defunto várias terras, com destaque para umas vinhas com seu lagar e casas por duzentos mil réis, vê-se obrigado a contrair um empréstimo mil réis para liquidar esta dívida, hipotecando as terras em questão ${ }^{38}$.

Já atrás falámos dos empréstimos realizados tendo em vista a compra de acções da Companhia Geral da Agricultura das Vinhas do Alto Douro. Para atrair capitais para os projectos do Estado, e para esta companhia em particular, a Coroa concedeu facilidades na contracção de empréstimos uma vez que «as justas considerações que me moverão a estabelecer a Companhia Geral da Agricultura dos Vinhos do Alto Douro me inclinarão

\footnotetext{
${ }^{34}$ AMC, Livro de Notas, № 20, fl. 26-27.

35 AMC, Livro de Notas, $\mathrm{N}^{\circ} 20$, fl. 112-115.

${ }^{36}$ AMC, Livro de Notas, No 21, fl. 80v-84.

${ }^{37}$ AMC, Livro de Notas, $\mathrm{N}^{\circ} 21$, fl. 152v-155.

${ }^{38}$ AMC, Livro de Notas, No 21, fl. 25v-27.
} 
tão bem a facelitar os meios de se intresarem nella os meus fieis vasalos» ${ }^{39}$. Assim, para toda a área abrangida pelo Tribunal da Relação do Porto foi proibida a realização de contratos de empréstimo de dinheiro a juros que não tivessem por fim a compra de acções da referida companhia. Os interessados em contrair um empréstimo com este propósito apresentavam à Mesa as cartas de habilitação régia e do Tribunal portuense, comprovando-se que eram detentor de bens de raiz necessários para cobrir a dívida e, visto tratar-se de quantias consideráveis, assegurava-se aos credores que ficariam «com hypotheca expecial em corrente quantia nas açois da mesma Companhia e com pinhoras nella», até porque se tratava de «hum banco publico no qual não pode naturalmente recearse falencia».

O dia 7 de Agosto de 1757 foi particularmente movimentado e sempre com o mesmo fim: contrair empréstimos para a compra de acções. Como já foi referido, este foi o motivo do empréstimo dos antigos provedor e escrivão, Francisco de Morais de Brito da Serra e António Xavier Zuzarte Maldonado Cardoso, 3.000 cruzados cada. Baltasar Jácome do Lago Rego, capitão dos granadeiros do Regimento de Aveiro, natural de Viana, obtém crédito de 5.000 cruzados e, a fechar este ano, aparece-nos o contrato de 4.000 cruzados que se celebra com D. António de Lencastre de Carvalho Fonseca e Camões de Meneses, da cidade de Guimarães. Estes dois últimos exemplos permitem-nos perceber que o raio de atracção da riqueza da Misericórdia conimbricense era vasto, talvez porque nem todas as suas congéneres tivessem capacidade para responder a tamanhas solicitações.

\section{Os contratos de nova fiança}

A consulta dos livros de notas permite constatar que, por vezes, os contratos não eram cumpridos ou sofriam alterações. A pressão de uma eventual execução por parte da Santa Casa motivava a celebração de novos contratos,

${ }^{39}$ Carta régia do dia 27 de Setembro de 1756, citada em escritura de 7 de Agosto de 1757, AMC, Livro de Notas, No 19, fl. 74-75. Sobre este assunto, ver LOPES, Maria Antónia A intervenção da Coroa nas instituições de protecção social de 1750 a 1820, Revista de História das Ideias, nº 29, 2008, p. 131-176. 
Gráfico 3 - Total de dinheiro envolvido nas novas fianças e declarações de dívida, em milhares de réis (Maio de 1753 a Junho de 1765)

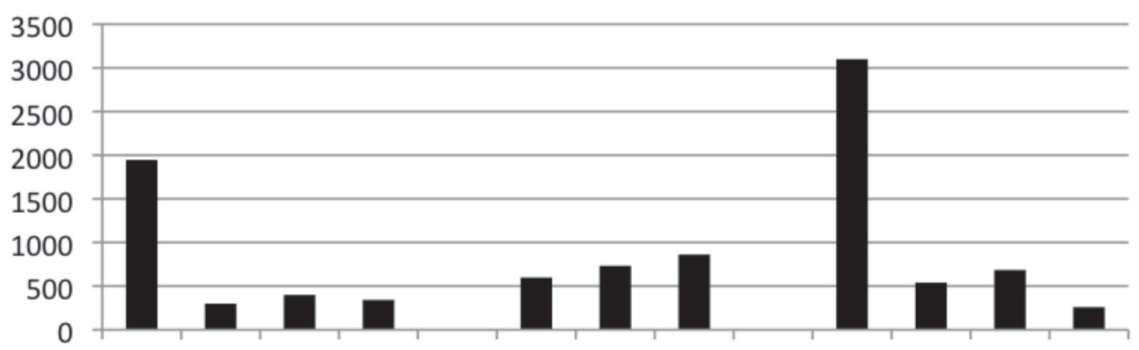

1753175417551756175717581759176017611762176317641765

Fonte: Arquivo da Misericórdia de Coimbra, Livro de Notas No 18 a 21

que declarando a dívida existente e asseguradas as hipotecas, prorrogava o prazo e estabelecia nova obrigação.

Da análise do gráfico podemos concluir que a máquina executória da instituição funcionava de forma relativamente eficaz, talvez reflectindo o rigor pretendido com o acórdão de 1748. No entanto, a consulta pormenorizada destes novos contratos permite vislumbrar o modo como as cumplicidades pessoais poderiam lesar os interesses da Misericórdia. No que respeita aos dinheiros envolvidos, embora a sua quantidade seja muito inferior quando comparada com a dos nos novos empréstimos, alcançavam, no entanto, somas consideráveis. Era também frequente o trespasse de dívidas.

O cónego João Lacerda Coutinho, antigo provedor da irmandade, contraíra um empréstimo de 9.000 réis na Misericórdia, dívida parcialmente saldada, restando pagar a quantia de 546 mil réis. Esta dívida será assumida, em 1753, por Calisto Rangel de Sá Pereira, que devia ao cónego 546 mil réis $^{40}$. Calisto Rangel volta a assumir uma dívida que um credor seu tinha para com a Santa Casa. Trata-se de Dionísio Macedo de Guimarães, herdeiro do primo Filipe Macedo de Guimarães, que «era obrigado a satisfação do legado que este deixou no testamento», mais precisamente um conto de réis a pagar num período de seis anos. No dia 9 de Maio de 1756, «temendo a morte» e para satisfazer a última vontade do falecido, entregou 657.620 réis

${ }^{40}$ AMC, Livro de Notas, No 18 , fl. 12-16v. 
em dinheiro, trespassando o restante da dívida, 342.800 réis, para Calisto Rangel de Sá Pereira ${ }^{41}$.

A pressão de uma eventual execução por parte da Santa Casa motivava por sua vez a revisão dos contratos existentes. E muitas vezes o argumento da morte do fiador era pretexto para prolongar o prazo do pagamento da dívida.

Em 1754 o irmão da Santa Casa Manuel Ribeiro Neves, ourives, foi notificado para proceder ao pagamento de 900 mil réis num prazo máximo de dez dias, cuja quantia estava assegurada pelos bens hipotecados. Como os fiadores por ele apresentados haviam falecido, pediu ao provedor e mais mesários «se dignasem conseder ao supplicante quinze dias pera no dito tempo suspensa a execução de que pagara as custas e dar nova fiança e rol de novos bens pera nova hipotequa», o que lhe foi concedido ${ }^{42}$. Em 1755 foi intimado Manuel Francisco da Cruz, mestre carpinteiro, para no prazo de dez dias pagar os 100 mil réis que devia à Misericórdia. Também neste caso falecera o fiador, mas como «esta Santa Caza não esta necessitada daquella quantia e o poderá por em outra mão a juro», foi feita nova obrigação de dívida, sendo apresentado como novo fiador António de S. Bento da Costa ${ }^{43}$.

A morte do fiador e os conflitos pessoais são o argumento invocado por João Adolfo Crato, Juiz da alfândega da Figueira da Foz, para refazer o contrato que tinha com a Misericórdia envolvendo um total de $600 \mathrm{mil}$ réis. O herdeiro do fiador, António Osório, «por mal afecto ao supplicante entrou a requerer para ser desobrigado da fiança» e fizera um requerimento à Mesa para que «se vendão os bens para pagamento dos ditos duzentos mil reis que so restão o que faz por odio». Tantas declarações de ódio são razão mais do que suficiente para que João Adolfo Crato realize, a 4 de Março de 1759, nova fiança para os 200 mil réis que estavam em falta, apresentando como novo fiador Raimundo António de Macedo ${ }^{44}$.

Curioso é o caso que nos aparece em 1753. A Misericórdia, pela sua função social, era um poderoso instrumento de controlo dos comportamentos. Daí que entre as suas obrigações estejam inscritos os dotes para facilitar o casamento de órfãs. E é precisamente a questão dos dotes, mas neste caso

\footnotetext{
${ }^{41}$ AMC, Livro de Notas, No 19 , fl. 62-64.

${ }^{42}$ AMC, Livro de Notas, No 18 , fl. $45-54 \mathrm{v}$.

${ }^{43}$ AMC, Livro de Notas, $\mathrm{N}^{\circ} 18$, fl. 74v-76v.

${ }^{44}$ AMC, Livro de Notas, $N^{\circ}$ 20, fl. 42-43.
} 
não visando o matrimónio, que leva a madre regente e restantes monjas do Recolhimento das Chagas de Cristo da vila de Pereira a recorrer à Mesa. Pretendiam assegurar o dote de 100 mil réis a que a religiosa D. Clara Angélica das Chagas tinha direito por testamento de seu tio, o cónego Francisco Lopes Teixeira. Talvez por estar contestado judicialmente, apresentam como fiança uma procuração feita a seu tio, cónego em Santa Cruz, padre D. José de Santo Agostinho Galvão Peixoto, onde se prova estar segura a dita quantia. Esperando o deferimento, que foi aceite, a religiosa termina a petição informando que «rogava a Deos pellos aumentos espirituais e temporais de todos os Senhores da Meza $»^{45}$.

Em 1755 é o correeiro Severino António e sua mulher que recorrem à Mesa, expondo um contratempo surgido, também ele relacionado com o dote. Informam na sua petição:

«para haverem de cazar foi a supplicante dotada como parente mais próxima do licenciado Manuel Suares de Oliveira no dote de quatrocentos mil reis que este havia deixado no testamento em que faleseo a favor de suas parentes no que fora provida no respectivo ao anno de mil e setecentos e cincoenta e quatro, respeito de cujo provimento pendia pleito movido por Joanna Suares do lugar do Monte São querendo primeiro ser gravada no dote por mais velha na idade ainda que mais remota no grau de parentesco, cuja disputa ainda que com embargos recebidos lhe não podia impedir a execução do provimento do dito não so pello privilegio do mesmo como porque não duvidava de o acautellar com fiansa idónea que queria prestar a sua reposição cazo obtivese por final sentença que fizese transito em julgado a dita proferente Joanna Suares $»^{46}$.

Esta contenda judicial embaraçava a própria Misericórdia, testamenteira de Manuel Soares de Oliveira, criador do Recolhimento das Órfãs ${ }^{47}$, pelo que não surpreende que o pedido tivesse sido deferido.

${ }^{45}$ AMC, Livro de Notas, $\mathrm{N}^{\circ} 18$, fl. 59-60v.

${ }^{46}$ AMC, Livro de Notas, $\mathrm{N}^{\circ} 19$, fl. 36.

${ }^{47}$ Acerca deste recolhimento veja-se LOPES, Maria Antónia-Pobreza, Assistência..., cit., vol. I, p. 485-523. 
Manuel de Brás, filho de Brás João, fiador dos 100 mil réis que o barbeiro Manuel das Chaves pedira a juros à Santa Casa, soube em 1758 que um chão do devedor fora penhorado. Interessado em adquirir a propriedade, fez nova escritura de obrigação «de toda a conta liquida que constar se esta devendo da primeira escriptura $»^{48}$.

O assumir de dívidas familiares é outra razão para as novas escrituras. Porque o contrato obrigava os herdeiros ao pagamento dos montantes em falta, o receio de uma execução é razão mais do que suficiente para novos contratos. É este o motivo do requerimento de José António de Oliveira e sua mulher de um empréstimo 160 mil réis, em 1758. O seu tio, o reverendo João da Fonseca, devia essa quantia à irmandade, o que justificou uma carta de arrematação dos bens hipotecados. Os suplicantes estavam interessados no trespasse da arrematação, disponibilizando-se para fazer escritura de obrigação da quantia em causa, além de se comprometerem com o pagamento de todas as despesas decorrentes do processo. O mesmo se passa com Lourença Josefa de Andrade, herdeira de Manuel Barbosa da Guerra, prestes a ser alvo de uma execução por este ter sido fiador de uma dívida de 119.269 réis. Ela assegura o pagamento da dívida, «porem não tem promto o dinheiro para o pagamento e os bens pinhorados excedião o valor de duzentos mil reis», razão pela qual faz também uma obrigação de dívida ${ }^{49}$. Em Mesa de 30 de Maio de 1759 o padre Cristóvão Francisco Manuel da Conceição vê-se na obrigação de fazer nova fiança de 100 mil réis, dado que o falecido seu pai, Domingos Francisco, fora fiador de uma dívida e a Misericórdia se preparava para executá-lo na qualidade de herdeiro ${ }^{50}$.

Concluímos esta apresentação de novas fianças com o caso de Bento de Andrade Pereira, inquiridor do juízo geral, e sua mulher, Ana Rosa da Panha. O casal havia arrematado à Misericórdia umas casas na Rua Direita que integravam a herança do benfeitor António Pinto Machado pela quantia de 700 mil réis. Este valor foi o montante do empréstimo contraído com a irmandade. Faltando pagar 350 mil réis, o casal solicita à Santa Casa uma nova fiança, hipotecando para tal as casas em questão ${ }^{51}$.

\footnotetext{
${ }^{48}$ AMC, Livro de Notas, $\mathrm{N}^{\circ} 20$, fl. $5 \mathrm{v}-7 \mathrm{v}$.

${ }^{49}$ AMC, Livro de Notas, No 20, fl. 37v-40.

${ }^{50}$ AMC, Livro de Notas, $\mathrm{N}^{\circ} 20$, fl. 69-70v.

${ }^{51}$ AMC, Livro de Notas, No 21, fl. 54v-56.
} 


\section{Os contratos de cessão, quitação e trespasse de dívidas}

Ainda no âmbito das dívidas à Santa Casa, temos o registo de algumas pagas na totalidade, a maioria pelos fiadores. Seguem-se alguns exemplos que comprovam o agrado da Misericórdia com a atitude dos fiadores, a quem delegava os poderes de execução que tinha na qualidade de credora. Já aos novos credores interessava sobretudo os bens hipotecados pelos devedores.

A 21 de Novembro de 1756 o irmão da Santa Casa, o ferrador Julião Gomes, fiador do empréstimo de 145 mil réis feito por António dos Santos e sua mulher em 1740, paga o que restava da dívida. Satisfeita a quantia à Santa Casa em «boas moedas de ouro e prata das correntes neste sitio», era concedido ao fiador «todo o direito que a Mizericordia credora tinha contra os ditos devedores para que delles ou de seos bens e herdeiros possa haver asi tudo o quanto por elles pagou da dita fiansa como seo legitimo credor ${ }^{52}$. Já em Julho desse mesmo ano clausula idêntica fora passada ao doutor Manuel Brás Ferreira. Ele saldara o que restava da dívida de 3.000 cruzados contraída por Gregório Ferreira e seu pai Domingos Ferreira Temudo, que se encontravam no continente americano. Como a Misericórdia não via forma de reaver o dinheiro procedeu à execução dos bens. Foi então que apareceu Manuel Brás Ferreira a satisfazer o dinheiro que estava em falta, recebendo um trespasse de direito contra os devedores, com a garantia da Misericórdia de que «se necessario hera a constituhião procurador em rem propriem para poder haver a si tudo quanto pagase pellos ditos devedores como que se fosse a Meza credora sedenta ajeitandoos como milhor lhe paresese ${ }^{53}$.

A 5 de Janeiro de 1757 Maria da Conceição, viúva de António Rodrigues Coura, e seu filho são executados de uma dívida que o falecido tinha para com a Misericórdia no valor de 150 mil réis e outra na qualidade de fiador de Manuel Francisco Pego, de 250 mil réis. Ora, «para não serem vexados», os interessados pagaram a totalidade das dívidas do defunto, bem como qualquer despesa inerente ao processo de execução. Em troca, a Misericórdia trespassou os direitos de execução que tinha contra Manuel de Francisco

\footnotetext{
${ }^{52}$ AMC, Livro de Notas, No 19 , fl. 68v-69.

${ }^{53}$ AMC, Livro de Notas, $\mathrm{N}^{\mathrm{o}} 19$, fl. 67v-68v.
} 
Pego $^{54}$. Dezoito dias depois aparece Dionísio de Macedo Guimarães que «tinha noticia que esta Santa Caza se achava executando ao Cappitão Francisco Grasia de Mello e a sua mulher moradores a Alegria extramuros desta mesma cidade pella quantia de outocemtos mil reis e seos juros de que lhe era devedor». Acontece que o executado também lhe fizera a penhora dos mesmos bens numa dívida de 400 mil réis de que era credor. Era sua opinião que os bens hipotecados chegavam para cobrir as duas dívidas se «vendidos com sucego e boa deligencia que convem so ser feita por hum dos credores», razão pela qual tomou o trespasse executório ${ }^{55}$.

Em 1758 Caetano Correia e Manuel Moreira, respectivamente filho e genro de José Correia e seus herdeiros, em resposta a uma execução da Santa Casa, pagam o que resta de uma dívida de 85 mil réis. É que o falecido José Correia fora fiador dos filhos do doutor Sebastião Rebelo Toscano e do capitão José Moreno Toscano. Estando a dívida saldada, conseguem que lhes sejam trespassados os direitos na qualidade de credores para poderem reaver a quantia despendida ${ }^{56}$.

A necessidade de maior eficácia na execução das dívidas é testemunhada no acórdão de 17 de Dezembro de $1766^{57}$, muito focado na acção caritativa da Misericórdia e, sobretudo, no seu bom-nome. A Mesa presidida por Bernardo Coutinho Pereira constata que muitas das práticas inerentes à natureza da instituição foram desvirtuadas ou abandonadas, nomeadamente «o santo e louvável costume de vizitar nas três festas do anno os presos encarcerados e os pobres doentes e intrevados» e o atraso no pagamento dos dotes e dos salários dos capelães da capela instituída pelo licenciado Manuel Soares de Oliveira. Diz o acórdão que medidas extremas como o endividamento da própria instituição são desnecessárias uma vez que

«examinandosse nesta mesma Meza as pautas das dividas que se estam devendo de juros atrazados e vencidos the o prezente achasse que so em pessoas principais desta cidade seo termo e comarqua devem de seos respectivos capitais asima de doze mil e quinhentos cruzados e

\footnotetext{
${ }^{54}$ AMC, Livro de Notas, No 19 , fl. 69v-70v.

${ }^{55}$ AMC, Livro de Notas, No 19, fl. 70v-71.

${ }^{56}$ AMC, Livro de Notas, No 20, fl. 18v-19v.

${ }^{57}$ Cf. ELIAS, Luís Filipe - A Misericórdia de Coimbra..., cit., p. 96-98 e 148-150.
} 
não he rezão nem convem a boa administração que esta Meza podendo cobrar estes reditos se haja de empinhar para satisfazer obrigaçoins dos testadores deixandosse ficar com elles na mão aos tais devedores».

E, como nos foi possível depreender da exposição que fizemos, muitos dos poderosos a que se refere o documento eram membros proeminentes da própria Santa Casa e, portanto, responsáveis pelas dificuldades económicas que sentia, quando faziam nesta uma gestão irresponsável, interesseira e permissiva, com o beneplácito óbvio dos outros irmãos. É, pois sem surpresa, que a orientação dada por esta Mesa é para

«se cuidasse na cobrança dos juros vencidos, procedendosse executivamente contra todos os devedores, atendendo a que tendosse praticado com elles as atençoens devidas ao respeito e authoridade de suas egrégias pessoas tem abuzado das mesmas atenções sabendo outrosim a consternação em que esta Meza se tem visto».

Esclarecedor este acórdão quando partilha as culpas: devedor que não paga o que deve, credora que não executa os montantes a que tem direito.

\section{A Coroa e o controlo do crédito}

A questão dos créditos malparados foi muitas vezes alvo de petições à Coroa. De acordo com informações prestadas pela Misericórdia, a dívida de juros ascendia aos 5.421.560 réis, sendo que a «maior parte dos devedores erão dos mais ricos» e não poucas vezes irmãos da instituição. Beneficiando da inoperância e lentidão da permissiva máquina burocrática da Santa Casa, atrasavam ao máximo o pagamento das dívidas com «grave detrimento dos pobres que não se podiam remediar». A provisão de 6 de Abril de 1761 permite ao juiz privativo da Misericórdia, o conservador da Universidade, que «faça cobrar e arrecadar executivamente todas as dividas e juros líquidos», ressuscitando-se o privilégio concedido à Santa Casa em 1617 «para puder executar e arrecadar as suas dividas na forma que os Almoxarifes e recebedores da minha Real Fazenda podião arrecadar 
e executar as rendas e dividas que a ella pertence». O juiz privativo ficava ainda obrigado, aquando da eleição anual da Mesa, a manter o Desembargo do Paço ao corrente das execuções para «evitarce por este modo que aconteça entrarem na dita Meza da Mizericordia pessoas que tornem a sufocar o meio executivo ${ }^{58}$. Aqui parece residir a explicação para que a Coroa, quando opta por nomear Mesas, relegar a aristocracia local para segundo plano.

Pombal volta à carga com nova provisão datada de 9 de Fevereiro de 1763, reforçando e ampliando a legislação anterior. Não parecem restar dúvidas de que os visados por estas provisões eram os poderosos locais, com destaque para o antigo provedor Filipe Saraiva de Sampaio e Melo ${ }^{59}$ que, segundo a informação prestada pelo juiz privativo, fora executado pela dívida de 2.710 .582 réis de juros vencidos. Recomenda-se a este magistrado que continue o seu trabalho na «cobrança e execuçoens das dividas que estão ainda por cobrar, pois não se mostram todas ellas extintas e toda a omissão he prejudicial a dita Santa Caza e obras pias da mesma $\rangle^{60}$.

Na década de setenta a Coroa amplia os poderes da Misericórdia, dandolhe meios para uma mais eficaz cobrança das dívidas. Pela provisão de 16 de Fevereiro de 1772, num argumento simples e coerente com a sua acção, a Coroa, reconhecendo que «sendo executiva a jurisdição» do juiz privativo, permite à irmandade dispor de um escrivão privativo «para mais facil expedição das ordens necessarias, separado dos dous escrivaens do Juizo» ${ }^{61}$.

É curioso o tratamento dado pela Coroa ao pedido de Francisco Colaço da Silva para um empréstimo de 13.000 cruzados, sendo a Misericórdia proibida de lhe conceder qualquer empréstimo «the a rezolução da consulta que se me fez sobre o requerimento» pelo próprio suplicante. Caso não fosse acatada a vontade régia, a pena era simbólica e pesada, uma vez que

${ }^{58} \mathrm{AMC}$ - Provisões que Sua Magestade tem concedido a Santa Caza da Mizericordia desta para o seu governo e cobrança das suas dividas, com outros documentos, fl. 11-11v.

${ }^{59}$ CF. LOPES, Maria Antónia - Provedores e Escrivães da Misericórdia de Coimbra..., cit., p. 215-216. Filipe Saraiva de Sampaio e Melo, acossado pelas provisões régias desta natureza, viu-se obrigado a vender o prazo que possuía em Vila Verde para saldar as dívidas que herdara de seu tio e as que contraíra.

${ }^{60}$ AMC, Provisões que Sua Magestade tem concedido..., cit., fl. $14 \mathrm{v}-15$ e Registo das Provisões I, fl. 141v-142.

${ }^{61}$ AMC, Provisões que Sua Magestade tem concedido..., cit., fl. 15v-16 e Registo das Provisões I, fl. 152-153. 
ficariam o provedor e mais mesários obrigados a repor «da vosa fazenda as quantias que em contravenção desta ordem tiverdes emprestado» ${ }^{62}$. O parecer favorável do Desembargo do Paço chega em forma de provisão mais de um ano depois.

\section{Conclusão}

$\mathrm{Na}$ elaboração deste artigo servimo-nos, sobretudo, da informação presente numa fonte pouco estudada, os livros de notas. Foi nosso objectivo dar um retrato do ainda desconhecido mundo dos solicitadores de crédito das misericórdias, tomando como exemplo o caso de Coimbra. Os dados recolhidos permitem traçar um panorama geral do sistema creditício da Misericórdia conimbricense no período em questão e que se insere numa prática administrativa nem sempre coerente e muitas vezes lesiva dos próprios interesses da instituição. E é-o sobretudo quando a gestão é feita não em prol da comunidade dos assistidos por obrigação, mas de interesses particulares. A situação económica a que chegaram muitas misericórdias espalhadas pelo país levou muitos historiadores a apontarem esta segunda metade do séc. XVIII como uma época de crise na história da instituição. $\mathrm{O}$ termo crise parece-nos excessivo, uma vez que estamos antes a assistir a uma adaptação das misericórdias a novos tempos e a novas exigências, o que nem sempre era fácil, dadas as vicissitudes locais e os interesses de quem nela se instalava. Mas esta «refundação» do papel da Santa Casa em contexto de Antigo Regime foi feita sob o olhar atento da Coroa que, na qualidade de protectora perpétua, teve um papel bastante interventivo e moralizador ${ }^{63}$.

\footnotetext{
${ }^{62}$ AMC, Registo das Provisões I, fl. 150v-151.

${ }^{63}$ LOPES, Maria Antónia - Parte II. De 1750 a 2000 in SÁ, Isabel dos Guimarães e LOPES, Maria Antónia - História Breve das misericórdias Portuguesas (1498-2000). Coimbra: Imprensa da Universidade de Coimbra, 2008, p. 74-80.
} 